\title{
Peyzaj Potansiyeli ve Kırsal Turizm İlişkisinin SWOT Analizi Yöntemiyle Değerlendirilmesi: Siirt İli Örneği
}

\author{
Arzu Altuntaş ${ }^{1 *}$ \\ ${ }^{1}$ Siirt Üniversitesi, Ziraat Fakültesi, Peyzaj Mimarlığı Bölümü, Siirt, Türkiye, (ORCID: 0000-0003-1258-3875)
}

(İlk Geliş Tarihi 20 Kasım 2019 ve Kabul Tarihi 22 Aralık 2019)

(DOI: $10.31590 /$ ejosat.636244)

ATIF/REFERENCE: Altuntaş, A., (2019). Peyzaj Potansiyeli ve Kırsal Turizm İlişkisinin SWOT Analizi Yöntemiyle Değerlendirilmesi. Avrupa Bilim ve Teknoloji Dergisi, (17), 1037-1044.

$\ddot{O} \mathbf{z}$

Bir ülkenin ekonomik kalkınmasındaki temel ve güçlü sektörlerden biri turizm sektörüdür. Turizm, kişilerin başta dinlenme olmak üzere gezme, kültürel deneyim elde etme ve bunun gibi amaçlarla ikamet ettikleri yerden başka bir yerde kalarak yaptıkları uğraşların tümüdür. Turizm faaliyetlerine katılan insanlar kendilerini özellikle fiziksel, zihinsel ve ruhsal olarak yenilerken, aynı zamanda, bu faaliyetleri gerçekleştirdikleri ülkenin ya da bölgenin ekonomisini canlandırmakta ve gelişimlerine de katkıda bulunmaktadırlar. Son yıllarda artan talep ve ihtiyaçlar turizmin çeşitlenmesini sağlamış, alternatif turizm türleri ortaya çıkmıştır. Kırsal turizm de bu türlerden biridir ve özellikle göçün artmaya başladığı yörelerde ekonomiyi canlandırmak, göçü durdurmak gibi amaçlarla ortaya çıkmıştır.

Ülkemiz başta coğrafi konumu olmak üzere sahip olduğu peyzaj potansiyeli, doğal ve kültürel değerleri ile turizm sektörünün geliştiği ülkelerden biridir. Bu özellikleri Türkiye'de alternatif turizm türlerinin gelişmesini ve yaygınlaşmasını da elverişli hale getirmektedir. $\mathrm{Bu}$ çalışmada ülkemizin Güneydoğu Anadolu Bölgesi’nde yer alan Siirt ilinin sahip olduğu peyzaj potansiyeli ve kırsal turizm açısından elverişliliğinin ortaya konulması amaçlanmıştır. Siirt, ekonomisi başlıca tarım ve hayvancılığa dayanan, nüfusunun yarısından fazlasının kırsal alanlarda yaşadığ 1 illerimizden biridir. Belirtilen amaç doğrultusunda ilin mevcut yapısı ortaya konulmuş ve literatür taraması, arazi gözlemleri, konuyla ilgili uzman görüşleri yardımıyla SWOT analizi yöntemiyle ilin kırsal turizm potansiyeli değerlendirilmiştir. Çalışmadan elde edilen veriler ve analizler doğrultusunda Siirt ilinin doğal ve kültürel yapısı ile kırsal turizm açısından bir potansiyele sahip olduğu, fakat bu potansiyelin kullanılabilmesinin doğru politikalar, teşvikler ve eylemlerle gerçekleştirilebileceği ulaşılan sonuçlar arasında yer almaktadır. Özellikle güvenlik konusunda bölgeye olan önyargının ortadan kaldırılması, yöre halkının kırsal turizm konusunda farkındalık ve bilinç düzeylerinin arttırılması da son derece önemli bulunmuştur.

\section{Evaluation of the Relationship between Landscape Potential and Rural Tourism by SWOT Analysis: The Case of Siirt Province}

\begin{abstract}
One of the basic and strong sectors in a country's economic development is the tourism sector. Tourism is all of the activities of people staying in a different place from where they live for the purposes of resting, traveling, obtaining cultural experience and so on. While participating in tourism activities, they renew themselves especially physically, mentally and spiritually, while at the same time they stimulate the economy of the country or region in which they carry out activities and contribute to their development. In recent years,
\end{abstract}

\footnotetext{
Sorumlu Yazar: Siirt Üniversitesi, Ziraat Fakültesi, Peyzaj Mimarlı̆̆1 Bölümü, Siirt, Türkiye, ORCID: 0000-0003-1258-3875, arzualtuntas@yahoo.com.tr
} 
increasing demand and needs have led to the diversification of tourism and alternative types of tourism have emerged. Rural tourism is one of these types and it has emerged for the purpose of revitalizing the economy and stopping migration especially in the regions where migration has started to increase.

Our country which has got a suitable geographical position, especially its landscape potential, natural and cultural values and so on is one of the countries where tourism sector develops. These features make Turkey eligible in terms of the development and diffusion of alternative types of tourism. In this study, it is aimed to reveal convenience of the landscape potential and rural tourism potential in Siirt, which is located in the Southeastern Anatolia Region of Turkey. Siirt is one of the provinces where the economy is mainly based on agriculture and stockbreeding and more than half of the population lives in rural areas. In line with the mentioned purpose, the existing structure of the province has been put forward and rural tourism potential of the province has been evaluated by SWOT analysis method with the help of literature survey, field observations and expert opinions. According to the data and analysis obtained from the study, Siirt province has a potential in terms of natural and cultural structure and rural tourism, but it is among the results that the use of this potential can be realized through correct policies, incentives and actions. It was also found extremely important to eliminate the prejudice against the region, and to increase the awareness of the local people on rural tourism.

Keywords: Tourism, Rural Tourism, Landscape Potential, Siirt, SWOT

\section{Giriş}

Turizm, insanların dinlenme, eğlence, kültürel deneyim, aile ziyareti, spor, sağlık, iş ve bunun gibi amaçlar sebebiyle kişisel ya da toplu olarak gerçekleştirdikleri, bulundukları yer dışında konaklamalarıyla ortaya çıkan bir eylem, sosyal bir olay, hizmet ve kültür endüstrisi olgusudur (Olalı vd. 1983, Topay 2003). Özellikle Endüstri Devrimi ile başlayan gelişmeler ve değişimler insanları turizm faaliyetlerine yönlendirmeye ve turizm de dünyadaki önemli ekonomik sektörlerden biri olarak gelişmeye başlamıştır.

Kişiler özellikle fiziksel, zihinsel ve ruhsal kapasitelerini arttırmak, rahatlamak, kendilerini yenilemek amacıyla turizm faaliyetlerine katılmakta ve standart turist tipini geride bırakmaktadır. Bugünün koşulları, dünyanın içinde bulunduğu olumsuzluklar, yaşam şartları insanların turizm ihtiyaçlarının artmasındaki en büyük etkenlerdir. Teknolojinin gelişmesi ve beraberinde getirdiği sorunlar, iş temposunun yoğunluğu, kirlilik düzeylerinin artması (hava, su, gürültü vb) doğal alanlara olan ilgiyi arttırmakta ve bunun sonucu olarak da alternatif turizm tiplerine olan talebin günden güne gelişmesini sağlamaktadır (Gülbay, 2016). Önceleri çok az insan tarafından sınırlı alanlarda yapılan alternatif turizm türleri, yeni arayışlar içine giren günümüz insanının keşfetme tutkusuyla birlikte daha geniş boyutlara ulaşmıştır (Yaşaroğlu, 1992; Yıldız ve Kalağan, 2008; Dönmez vd. 2016). Alternatif turizm türlerinden biri de kirsal turizmdir.

Kırsal turizm, özellikle ekonomik sıkıntılar nedeniyle nüfusun azalmaya başladığı kırsal alanlarda, ekonomiye katkı sağlayarak göçün önüne geçmeyi amaç edinen turizm faaliyetidir. Ülkemizde kırsal denildiğinde akla doğrudan "kırsal alanlar" gelmektedir. Bu nedenle yayla turizmi, av turizmi, mağara turizmi, ekoturizm ve açıkhava doğa sporları gibi turizm faaliyetleri de kırsal turizm olarak değerlendirilmektedir. Aslında bu durum yanlış olmamakla birlikte kırsal turizmi tam olarak karşılamamaktadır. Çünkü kırsal turizmde konaklama bir köyde, dağ evinde ya da çiftlikte gerçekleşmekte; kırsal turizme katılan insanlar kaldıkları yörenin kırsal kültürüyle tanışmakta ve kaynaşmakta, böylece tatil zamanlarını bu şekilde geçirmektedirler. Bu açıdan bakıldığında da amaç, etkinlikler ve uygulamalar konusunda bazı farklılıklar ortaya çıkmaktadır (Soykan, 2003). Soykan (1999) ve Soykan (2003)'e göre kırsal turizm kırsal kültür, doğal çevre ve tarımla bütünlesen, ayrıca diğer turizm türleriyle de son derece kolay entegre edilebilen bir turizm türüdür. Bundan dolayı yerel, ulusal ve uluslararası düzeylerde zenginleştirilebilen içeriği sayesinde dünyanın birçok ülkede insanları kırsal alanlara çekebilmektedir.

Doğa Koruma ve Milli Parklar Genel Müdürlüğü (2013)’ne göre, kırsal turizmin gelişmesi ve sürdürülebilir olması için birtakım kriterler bulunmaktadır. Bunlar biyolojik çeşitliliğin korunması, ekonomik tutarlılık, kültürel zenginlik, yöre halkının refahı, istihdam kalitesi, sosyal eşitlik, ziyaretçi memnuniyeti, yetkinin yerele doğru dağıtılması, toplumun genelinin refah ve mutluluğu, fiziki bütünlük, kaynakların etkin kullanımı ve çevre temizliği ölçütleridir.

Türkiye sahip olduğu doğal ve kültürel özellikleri ile önemli bir turizm merkezidir. Ülkemizin neredeyse her bölgesi alternatif turizm türleri için son derece elverişli olmakla birlikte özellikle Doğu ve Güneydoğu illerimiz birtakım nedenlerden (güvenlik, mesafe vb) dolayı turizm faaliyetlerinden hak ettikleri karşılığı alamamaktadır. Bu çalışmada Siirt ili örneğinde kırsal turizm potansiyelinin ve kırsal turizmin bölgeye sağlayacağı katkının değerlendirilmesi amaçlanmıştır.

\section{Materyal ve Metot}

\subsection{Materyal}

Araştırma alanı Siirt ili idari sınırlarıdır. Güneydoğu Anadolu Bölgesi’nde $41^{\circ} 57^{\prime}$ doğu boylamı ve $37^{\circ} 55^{\prime}$ kuzey enlemi üzerinde dağlık bir alanda yer alan Siirt, doğudan Van, batıdan Batman, kuzeyden Bitlis, güneyden Mardin ve Şırnak illeri ile çevrilidir (Şekil 1). 


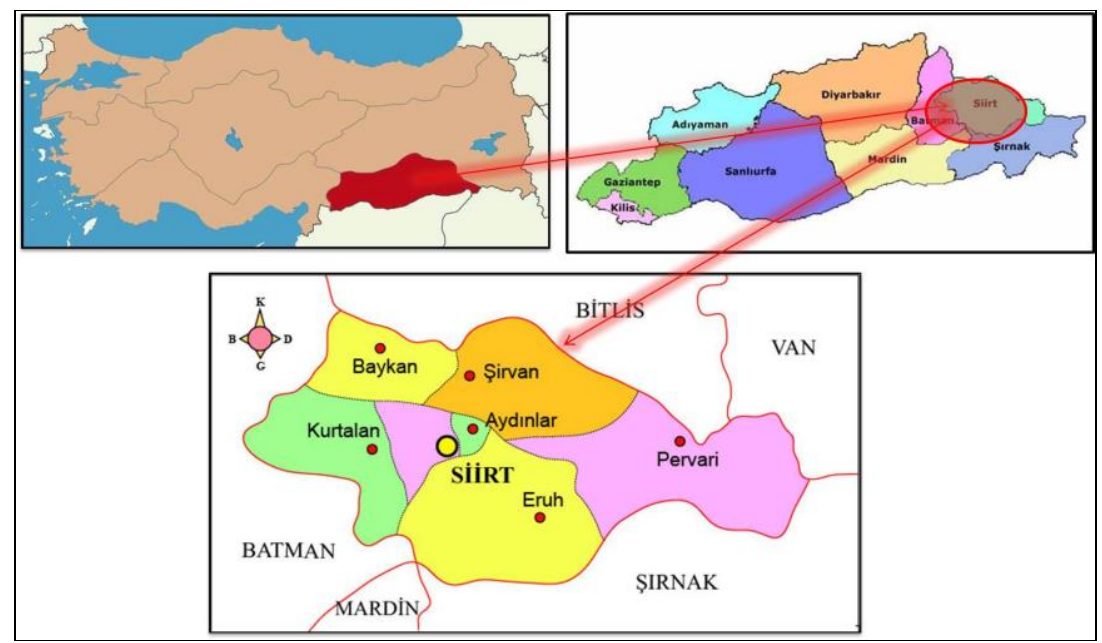

Şekil 1. Siirt ilinin coğrafi konumu

Araştırma alanının seçiminde Siirt ilinin doğal, kültürel, tarihsel ve dinsel özellikleri, bölgede yer alan ve turizm açısından dikkat çeken merkezlere yakınlığı, kırsal turizm ve diğer alternatif turizm çeşitleri için uygun bir potansiyele sahip olması ve yöre halkı için bir başka ekonomik gelir kaynağı oluşturacağı düşüncesi etkili olmuştur. Alanla ilgili özellikler Orman ve Su İşleri Bakanlığ1 (2014), Çevre ve Şehircilik Bakanlığı (2013), Doğa Koruma ve Milli Parklar Genel Müdürlüğü (2013), Meteoroloji Genel Müdürlüğü (2014), TÜBIVES (2015), Siirt Valiliği (2015), Siirt Belediyesi (2017), TÜíK (2018), GAP Bölge Kalkınma İdaresi Başkanlığı (2015) tarafından yapılan çalışmalardan, literatür taramalarından, yöre halkı ile yapılan görüşmelerden ve gözlemlerden elde edilen verilerle ortaya konulmuştur.

\subsubsection{Metot}

Siirt ili örneğinde kırsal turizm potansiyelinin ve kırsal turizmin bölgeye sağlayacağı katkının değerlendirilmesi amacıyla gerçekleştirilen bu çalışmada öncelikle Siirt ile ilgili veriler toplanarak sahip olduğu doğal, kültürel, tarihsel vb özellikler belirlenmiştir. Daha sonra SWOT Analizi yöntemiyle bölgenin kırsal turizm potansiyeli irdelenmiştir. SWOT Analizinde elde edilen tüm veriler değerlendirilerek S (Strength: güçlü yönler), W (Weakness: zayıf yönler), O (Opportunity: firsatlar) ve T (Threat: tehditler / tehlikeler) ortaya konulmaktadır. Bu yöntem kırsal turizm olanaklarının belirlenmesinde araştırmacılar tarafından kullanılan bir yöntemdir. Spatariu vd (2010), Çeltek (2004), Ongun ve Gövdere (2014), Soykan (1999), Soykan (2003), Ongun vd (2016), Mansuroğlu ve Dağ (2016) gibi araştırmacılar örnek alanlarda benzer çalışmalar yürütmüşlerdir. Ayrıca çalışmada arazi gözlemlerinden ve uzman görüşlerinden de faydalanılmıştır.

\section{Bulgular}

\subsection{Siirt İli Doğal Özellikleri}

6.186 km²’lik yüzölçümüne sahip Siirt ili 895 rakımlı olup Güneydoğu Anadolu Bölgesi’nin kuzeydoğusunda yer almaktadır. Dicle Irmağı, Botan Çayı, Garzan Çayı, Kezer Çayı ve Behranca Deresi en önemli akarsularıdır (Anonim, 2018).

Yıllık ortalama sıcaklığın $16,1^{\circ} \mathrm{C}$ olduğu ilde kış ayları sıcaklık ortalaması $2,7-4,8^{\circ} \mathrm{C}$ arasında değişmekte ve yaz ayları sıcaklık ortalaması ise $30,5^{\circ} \mathrm{C}$ civarındadır. Sicaklığın en düşük olduğu ay Ocak, sıcaklığın en yüksek olduğu ay ise Ağustos ayıdır. $1960-2013$ yılları arasında Ocak ayında ölçülen en düşük sıcaklık $-15,6^{\circ} \mathrm{C}$ ve Ağustos ayında ölçülen en yüksek sıcaklık değeri ise $46,0^{\circ} \mathrm{C}$ 'dir. İlin yıllık ortalama yağış miktarı ise 691,5 mm'dir. Aylık en yüksek yağış miktarı 104,4 mm ile Mart ayında, en düşük yapış miktarı ise 1,0 mm ile Ağustos ayında görülmektedir (Anonim, 2015).

Anonim (2013a)'e göre Siirt ilinin \% 75'i dağlarla ve \% 22'si ise ovalarla kaplıdır. İlin özellikle kuzeyinde ve doğusunda yüksek ve sarp kesimler bulunmaktadır. Siirt'te bulunan ve ili çevreleyen belli başlı dağlar Tandır Dağı (2.170 m), Garzan Dağı (1.055 m), Hasteri Dağı (2.700 m), Doğruyol Dağı (2.650 m), Tartı Tepe (2.268 m), Tünek Dağı (2.100 m), Yazlıca Dağı (2.943 m), Körkandil Dağı $(2.821 \mathrm{~m})$ ve Martepe Dağı $(2.812 \mathrm{~m})$ 'dır.

Yapılan araştırmalar sonucunda ilin jeolojik yapısı değişik yaş gruplarında başkalaşım kayalarının olduğunu göstermektedir. Bunlar arasında özellikle Siirt - Bitlis arasındaki başkalaşım kayaları serisi en eski olan gruptur. "Midyat Kalkerleri” denilen oluşumlara da yoğun bir şekilde rastlanmaktadır. Bu oluşumlar özellikle Merkez ilçenin güneyinde yoğun olarak görülmektedir. Ayrıca "Cas taşı" olarak bilinen ve eski yapılarda harç malzemesi olarak kullanılan jipslere de rastlanmaktadır (Anonim, 2013a). Cas taşı yöre mimarisini şekillendirmiş ve Cas evleri olarak bilinen yapıların da inşa edilmesinde kullanılmıştır (Şekil 2). 


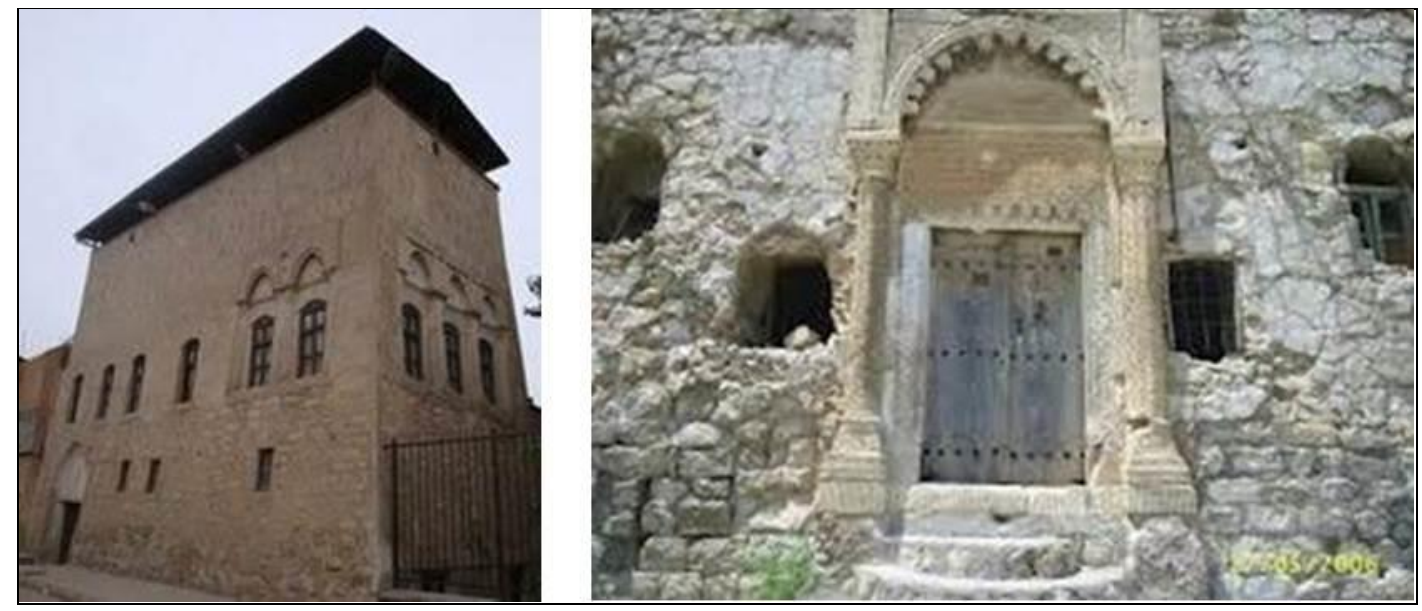

Şekil 2. Cas evleri (Anonim, 2013b)

Yaklaşık olarak \%35'i orman ve koruluklarla kaplı olan il orman varlığı bakımından zayıf bir karakter göstermektedir. Bu alanların \% 75'i boşluklu kapalı koru ve geri kalanı ise normal kapalı koru ve orman şeklindedir. Çayır ve mera alanlarının oranı \%6 civarındadır. En sık rastlanan orman ağacı türü Quercus brantii (İran palamut meşesi)'dir (Anonim, 2013a). Siirt fistığı adıyla bilinen Pistacia vera L. (Şekil 3) türü ile bıttım adıyla bilinen Pistacia khinjuk (Şekil 4) da ilde yaygın olarak bulunan ve yöre halkı tarafından özellikle ekonomik amaçla yetiştirilen türlerdir. Bu türlerin dışında söğüt, kavak, karaçam, çınar, ardıç, sumak gibi türler bulunmaktadır.
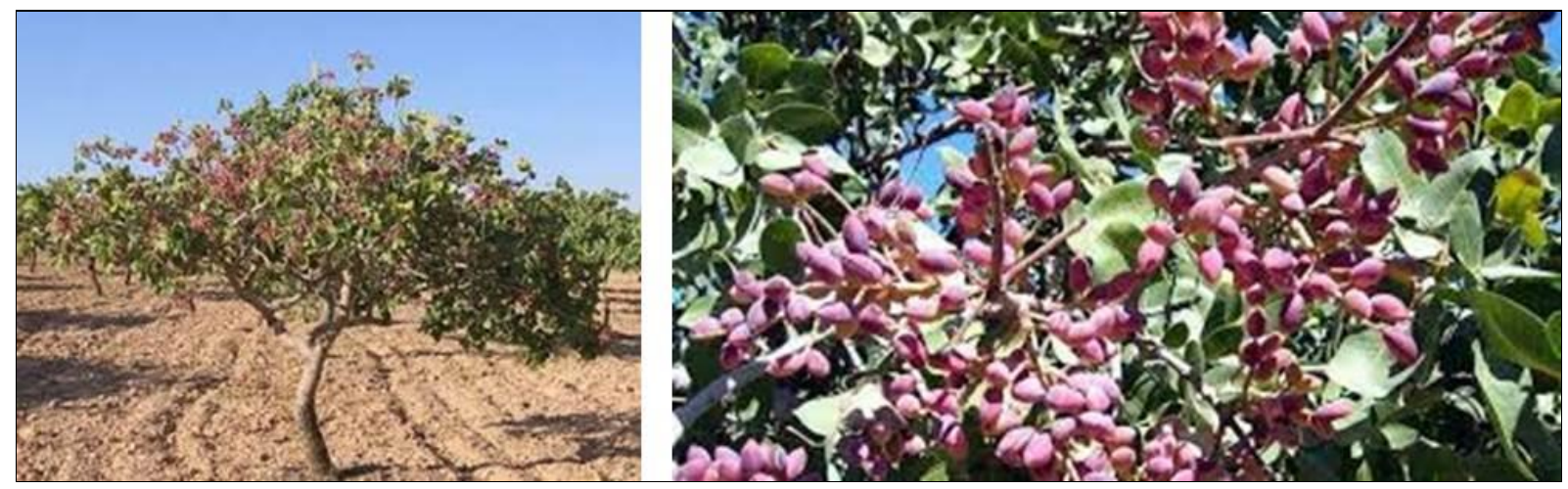

Şekil 3. Pistacia vera L. (Anonim, 2019b)

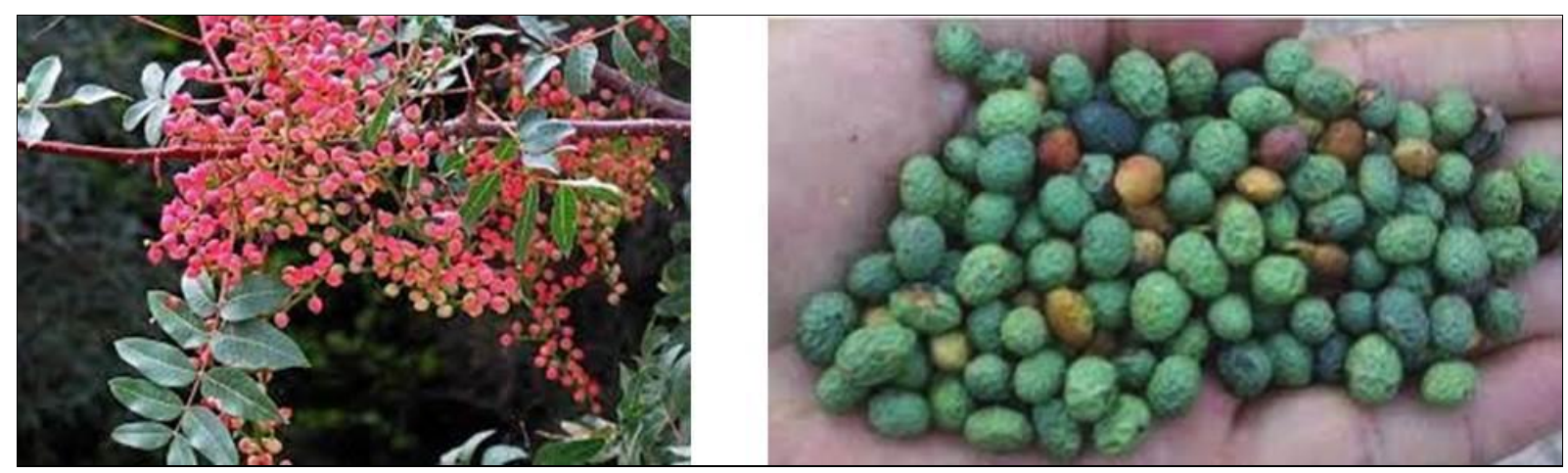

Şekil 4. Pistacia khinjuk (Anonim, 2019b)

TÜBIVES (2015) verilerine göre Siirt’te 320 bitki taksonu tespit edilmiş olup bunlardan 43 adedi endemik tür olarak tescillenmiştir. 2017 yılında ise Siirt'in Pervari ilçesinde, Allium pervariensis adı verilen yeni bir endemik tür tespit edilerek kayıt altına alınmıştır (Anonim, 2018). Bu endemik türler arasında özellikle Salvia siirtica (Siirt adaçayı) ve Hyecintella siirtensis (Siirt kopçası), Fritillaria imperialis (Ters lale) ve Populus firatica (Fırat kavağı) en fazla bilinen türlerdir.

Siirt ili fauna varlığı konusunda yeterince çalışma bulunmamasına karşın; özellikle Buteo rufinus (şahin), Circaetus gallicus (kartal), Falco biarmicus feldegg (doğan), Gyps fulvus (akbaba), Sterna hirundo (kırlangıç), Alectoris chukar cypriotes (keklik), Ardea cinerea (balıkçıl kuşu), Carduelis Carduelis (saka), Lynx caracal (karakulak), Felis chaus (sazlık kedisi), Mustela nivalis (bayağı gelincik), Hyaena hyaena (çizgili sırtlan) gibi türlerin varlığından söz etmek mümkündür (Anonim, 2013a). 
Siirt ili Tillo ilçesinde 40 hektar alana sahip Tillo Tabiat Parkı bulunmaktadır (Şekil 5). Alan 2014 yılında tabiat parkı olarak ilan edilmiş olup 2018 yılında kullanıma açılmıştır. İçerisinde kır kahvesi, kır lokantası, idare binası, ziyaretçi merkezi, yöresel ürün satış birimleri, büfe, WC mescit, pergolalar ve otopark alanları bulunmakta olup ziyaretçiler tarafından günübirlik olarak kullanılmaktadır. Ayrıca Botan Vadisi ve Deliklitaş, Siirt ilinde bulunan doğal peyzaj özellikleri arasında yer almakta olup Botan Vadisi özellikle yamaç paraşütü açısından tercih edilmektedir (Şekil 6).

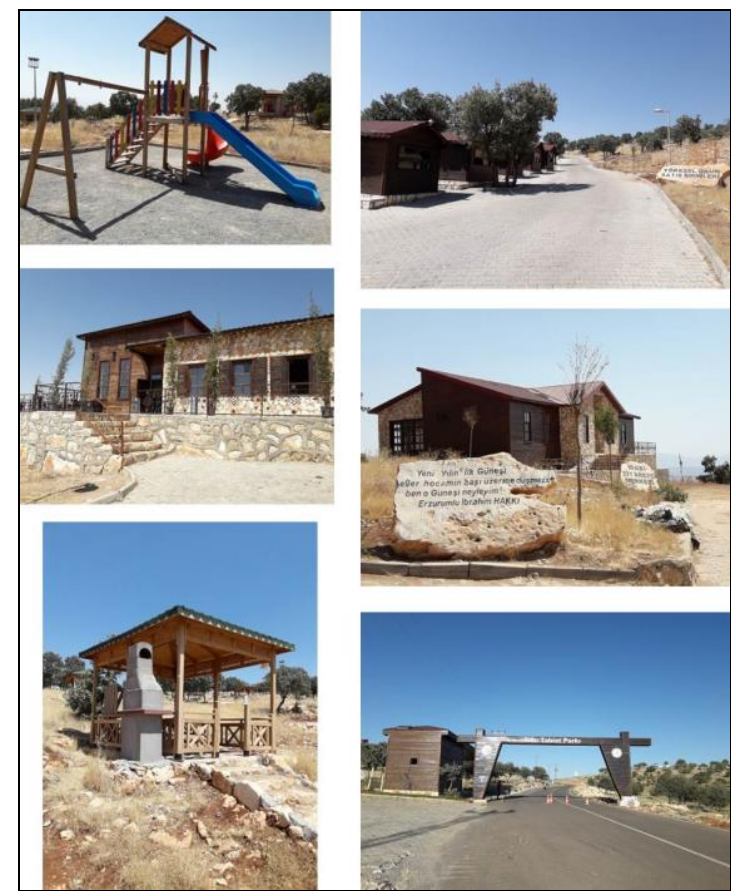

Şekil 5. Tillo Tabiat Parkı (Orijinal, 2018)

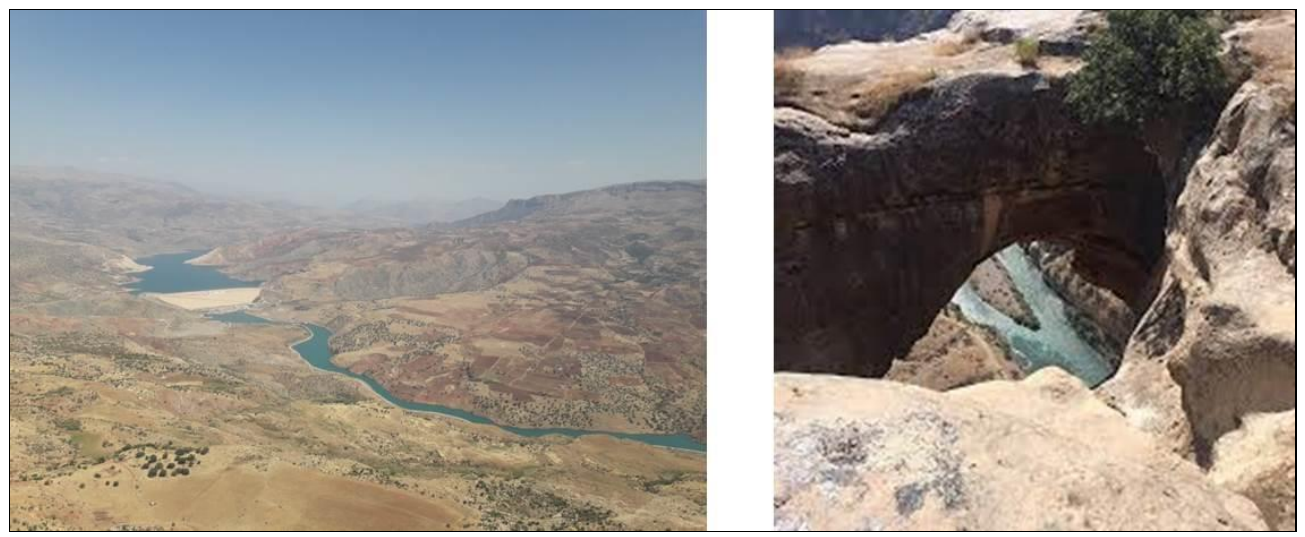

Şekil 6. Botan Vadisi ve Deliklitaş (Orijinal, 2018)

\subsection{Siirt İli Kültürel Özellikleri}

Siirt ve çevresi, milattan önceki yıllarda Samiler, Babil ve Asur İmparatorlukları, Medler ve Perslerin egemenliği altında bulunurken; milattan sonraki yıllarda ise Romalılar, Partlar ve Sasanilerin hakimiyeti altına girmişlerdir (Anonim, 2013a).

Türklerin Anadolu’ya yerleşmesinin ardından Türk beylikleri ve sonrasında Selçukluların yönetiminde kalan bölge 1514 Çaldıran Savaşı ile birlikte Osmanlı İmparatorluğu’na katılmıştır (Anonim, 2013a).

Osmanlı İmparatorluğu döneminde önce Diyarbakır'a, sonra da Van’a bağlı bir sancak olan Siirt, Cumhuriyetin ilanı ile birlikte il olmuştur. 1990 yılında Batman ve Şırnak ilçelerinin il olmasıyla birlikte Siirt yeniden yapılandırılmıştır. Siirt ili bugün artık Merkez, Aydınlar (Tillo), Baykan, Eruh, Kurtalan, Pervari, Şirvan olmak üzere 7 ilçeden oluşmaktadır (Anonim, 2019a).

İlde çeşitli zamanlarda yapılan birtakım eserler bulunmaktadır. Bunlar arasında en önemlileri arasında Veysel Karani Türbesi, Sultan Memduh Hazretleri Türbesi, Şeyh Muhammed Kazım Türbesi, İrun Kalesi kalıntıları, Derzin Kalesi kalıntıları, Şeyh Hamza El-Kebir Hazretleri Türbesi, Kalet'ül Üstad kalıntıları, İbrahim Hakkı Hazretleri Türbesi, İsmail Fakirullah Hazretleri Türbesi, İncekaya (Kormas) Kalesi kalıntıları, Şeyhul Hazin Hazretleri Türbesi, Şeyh İbrahim El Mücahid Türbesi, Zemzem-ül Hassa Hatun 
Türbesi, Gusir Höyük, Ulu Cami ve Cumhuriyet (Hıdr-ul Ahdar) Cami gelmektedir (Şekil 7) (Anonim, 2019a). Ayrıca milattan önceki devirlerde yapılan ve "zor geçit" anlamına gelen Akabe Yolu da Siirt’te bulunmaktadır.

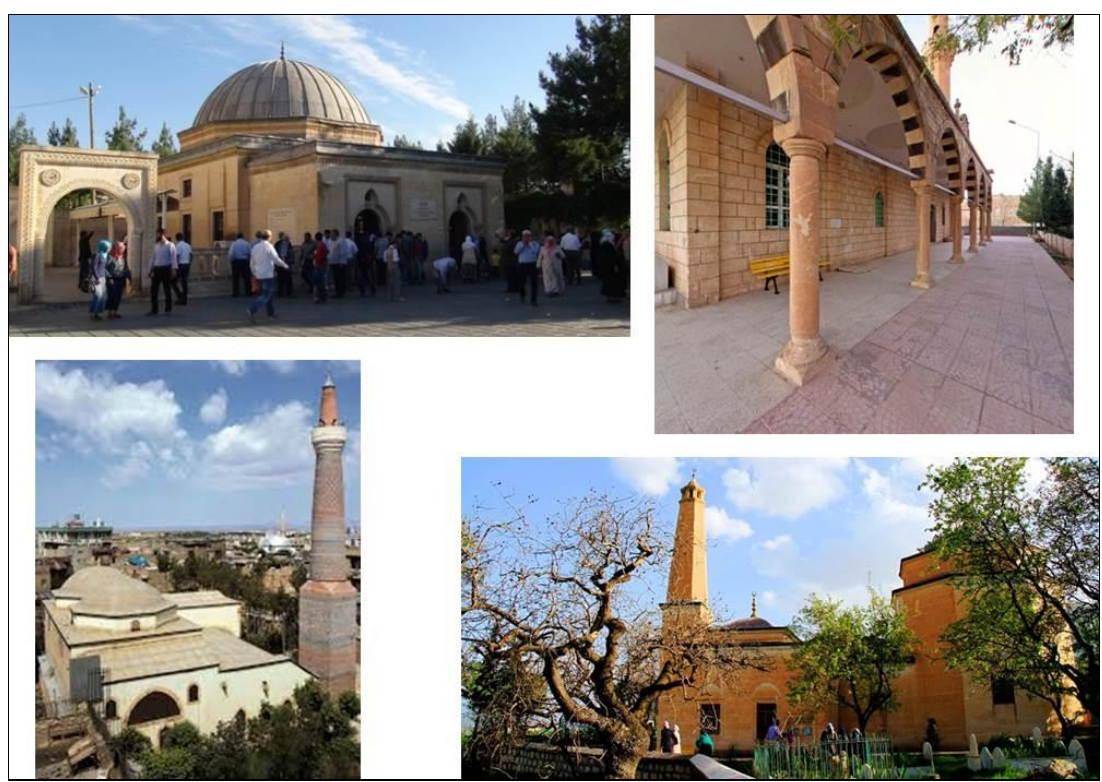

Şekil 7. Siirt ili türbelerinden bazıları (Orijinal, 2018)

\subsection{Siirt İli Sosyo-ekonomik Özellikleri}

Merkez ilçe ile birlikte toplam 7 ilçeden (Aydınlar (Tillo), Baykan, Eruh, Kurtalan, Pervari, Şirvan) oluşan Siirt ilinin nüfusu TÜIK (2018) verilerine göre 331.670 kişidir (TÜiK, 2018). Siirt iline bağlı 63 mahalle ve 275 köy bulunmaktadır. 2018 y1lı itibariyle 166.332 kişi merkez ilçede yaşarken nüfusun geri kalanı diğer ilçe ve köylerde ikamet etmektedir (Tablo 1).

Tablo 1. Siirt İli Nüfus Verileri (TÜiK, 2018)

\begin{tabular}{llll}
\hline İlçe Adı / Yıllar & $\mathbf{2 0 0 7}$ & $\mathbf{2 0 1 3}$ & $\mathbf{2 0 1 8}$ \\
\hline Baykan & 28561 & 27323 & 26160 \\
\hline Eruh & 19447 & 19903 & 20513 \\
\hline Kurtalan & 55076 & 58033 & 59647 \\
\hline Merkez & 127881 & 152539 & 166332 \\
\hline Pervari & 32642 & 32453 & 32128 \\
\hline Sirvan & 24054 & 23986 & 22580 \\
\hline Tillo & 3867 & 4129 & 4310 \\
\hline TOPLAM & $\mathbf{2 9 1 5 2 8}$ & $\mathbf{3 1 8 3 6 6}$ & $\mathbf{3 3 1 6 7 0}$ \\
\hline
\end{tabular}

Siirt ili ekonomisi tarım ve hayvancılığa dayanmaktadır. GAP Bölge Kalkınma İdaresi Başkanlığı’nın 2019 yılı verilerine göre Siirt ili toplam tarım alanı 89.454 ha'dır. Bunun $\% 56,8$ 'i tahıl ve diğer bitkisel ürün yetiştirmede, \%35,5'i meyve, içecek ve baharatlı bitki üretiminde, \%2,1'i ise sebze bahçesi olarak kullanılmaktadır. Tarım alanlarının \%5,6'sı nadasa bırakılmaktadır.

Siirt ili büyükbaş hayvan varlığı 34.918 , küçükbaş hayvan varlığı 1.250 .1453 'tür. Arıcılık ise bölgenin geçim kaynaklarından biridir (GAP Bölge Kalkınma İdaresi Başkanlığı, 2019).

Sanayi sektörünün gelişmesi amacıyla bölgesel ve sektörel açıdan teşvik politikaları düzenlenerek yeni yatırımlar teşvik edilmektedir. İlde 1 adet organize sanayi bölgesi ve 1 adet küçük sanayi sitesi bulunmaktadır. 2016 yıll itibariyle Siirt ili imalat sanayi tesisi sayısı 69 'dur. Gıda sektöründe 20, tekstil ve deride 1, kimya - petrol ve plastikte 13, taş ve toprağa dayalı sanayide 24, makine - metalde 7 , orman ve kâğıt ürünlerinde 4 adet firma üretim yapmaktadır (GAP Bölge Kalkınma İdaresi Başkanlığı, 2019).

GAP Bölge Kalkınma İdaresi Başkanlığı'nın uyguladığı Entegre Kırsal Kalkınma Programı’na göre 2012 yılından beri Zivzik narı yetiştiriciliği, Siirt fistı̆̆ı, sumak, bıttım üretimi, organik tarım, organik arıcılığın ve seracılığın geliştirilmesi ve yaygınlaştırılması projeleri gibi projeler desteklenmektedir (GAP Bölge Kalkınma İdaresi Başkanlı̆̆ı, 2019).

Bunların dışında 2011 yılında GAP Bölgesi Turizm Master Planı hazırlanarak onaylanmıştır. Bu plana göre bölgenin korumakullanma dengesi gözetilerek bütüncül bir yaklaşımla ve turizm odaklı olarak değerlendirilmesi, istihdam oranının arttırılması, turizm hareketlerinin daha sürdürülebilir olması ve turizmden elde edilecek gelirin arttırılması amacıyla markalaşma ve tanıtım faaliyetlerinin geliştirilmesi amaçlanmıştır. Bu bağlamda bir eylem planı hazırlanmış, haritalar üretilmiş, saha çalışmaları yapılmış, 
tanıtımlarla ilgili bölge paydaşlarından geribildirimler alınmış, tematik ve kent rotaları oluşturulmuş ve internet destekleri sağlanmıştır (GAP Bölge Kalkınma İdaresi Başkanlı̆̆ı, 2019).

\subsection{Siirt İli Kırsal Turizm Olanaklarına İlişkin SWOT Analizi}

\begin{tabular}{|c|c|}
\hline Güçlü Yönler (S) & Zayıf Yönler (O) \\
\hline $\begin{array}{l}\text { - Yörenin bozulmamış bir peyzaj potansiyeline } \\
\text { sahip olması } \\
\text { - Yöre halkının misafirperverliği } \\
\text { - Yöredeki tarım alanlarının miktarının fazla olması } \\
\text { ve organik tarıma uygun alanların çok olması } \\
\text { - Topoğrafik yapının yayla gezileri ve günübirlik } \\
\text { rekreasyon aktiviteleri için uygun olması } \\
\text { - Siirt'in coğrafi işaretlerinin çeşitliliği ve endemik } \\
\text { türlerin varlığı } \\
\text { - Botan Vadisi } \\
\text { - Yamaç paraşütü ve yürüyüş rotaları }\end{array}$ & $\begin{array}{l}\text { - Yöre halkının kırsal turizm konusunda yeterli } \\
\text { bilgiye sahip olmaması } \\
\text { - Yörenin yeterince tanıtımının ve reklamının } \\
\text { yapılmaması } \\
\text { - Konaklama birimleri ve otel sayısında yetersizlik } \\
\text { - Köyden kente göçün artması ve kırsal nüfusun } \\
\text { azalma eğiliminde olması }\end{array}$ \\
\hline Firsatlar (W) & Tehditler (T) \\
\hline $\begin{array}{l}\text { - } \begin{array}{l}\text { Kırsal turizme olan ilginin artması } \\
\text { - Yakınlarındaki yerleşimlerin }\end{array} \\
\text { potansiyellerinin yükssek olması (Mardin, } \\
\text { Hasankeyf, Van...) } \\
\text { - "Kırsal Turizmi Destekleme Programı" } \\
\text { kapsamında komşu iller olan Van ve Mardin'de } \\
\text { uygulanan projelerin bulunması } \\
\text { - Din turizmi açısından çok elverişli bir alan } \\
\text { olması, özellikle Veysel Karani ve İbrahim Hakk1 } \\
\text { Hz. Türbeleri'nin ilde olması } \\
\text { - Havaalanının bulunması } \\
\text { - Karayolu bağlantılarının olması } \\
\text { - Demiryolu ulaşımının olması (Kurtalan Tren } \\
\text { İstasyonu'ndan) } \\
\text { - GAP Bölgesi Turizm Master Planı'nın bulunması }\end{array}$ & 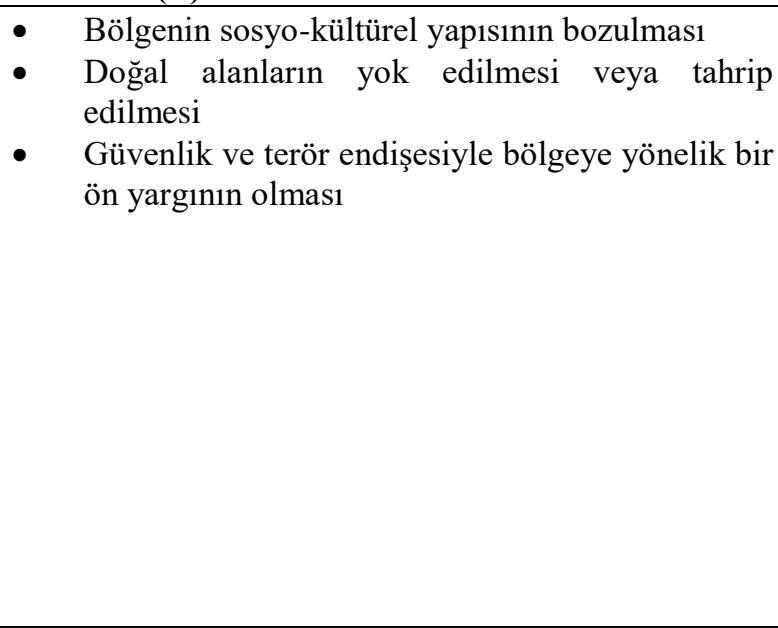 \\
\hline
\end{tabular}

\section{Sonuç}

Türkiye başta doğal vetarihi zenginlikleri ve bunun sonucunda oluşan turizm çeşitliliği ile son derece zengin ve turizm açısından firsatlarla dolu bir ülkedir. Fakat Türkiye sahip olduğu bu turizm potansiyelini yeterince kullanamamakta, diğer ülkelere göre bu sektörden daha az gelir elde etmektedir. Bu durumun en önemli sebeplerinin başında kaynakların akılcı ve rasyonel kullanılamaması gelmektedir. Oysaki dünyanın diğer ülkeleri, ellerinde daha az imkan ve kaynak olmasına rağmen, bunları en verimli şekilde değerlendirerek çk daha fazla gelir elde etmekte ve ekonomilerini geliştirmektedirler. Gülbay (2016)'ya göre ülke ölçeğinde turizm sektörünün gelişmesi ve ilerlemesi ancak bölgeler arası gelişmişlik farklarının azaltılması, turizmden elde edilen gelirlerin artması, alternatif turizm çeşitlerinin yaygınlaştırılması ve iç göçün ortadan kaldırılmasıyla mümkün olabilecektir.

Ülkemizde bulunan diğer illerde olduğu gibi Siirt ili de sahip olduğu turizm potansiyeliyle bu alanda geliştirilebilecek iller arasında yer almaktadır. Fakat bunun için, hazırlanan eylem planlarının yanı sıra yöre insanının, bölge ve il karar vericilerinin de konuyla ilgili belirgin adımlar atması oldukça önemlidir. Öncelikli olarak yöre halkının eğitilmesi, turizm ve alternatif turizm konusunda farkındalık yaratılması ve konu hakkındaki bilinç düzeyinin arttırılması bu adımların başında gelmektedir. Bir diğer önemli nokta ise ilin sahip olduğu peyzaj potansiyeline ilişkin envanter oluşturulmasıdır. Yerel ve bölgesel düzeyde kurumlar arası işbirliği, gerekli envanterin hazırlanması sürecini hızlandırabilecek bir durumdur.

Siirt ili alternatif turizm olanaklarının arttıılması ve geliştirilmesi amacıyla yerel halka eğitim verilmesi ve bu eğitimlerle birlikte yerel ve bölgesel düzeyde festival ve etkinliklerin oluşturulması da atılabilecek somut adımlar arasında yer almaktadır. Bunlarla ilgili reklam ve tanıtımlar gerçekleştirilmeli, özellikle turizm yatırımlarının artırılması amacıyla yerel girişimciler teşvik edilmelidir. 


\section{Kaynakça}

Anonim, (2013a). Siirt İlinde Doğa Turizmi Master Planı: 2013 - 2023. (mülga) T.C. Orman ve Su İşleri Bakanlığı Doğa Koruma ve Milli Parklar Genel Müdürlüğü, Siirt Şube Müdürlüğü, Siirt.

Anonim, (2013b). Cas Evleri. https://www.turkeyfromtheinside.com/places-to-go/s/187-srt.html (Erişim tarihi: 05.08.2019)

Anonim, (2015). Tillo Tabiat Parkı Gelişme Planı. (mülga) T.C. Orman ve Su İşleri Bakanlığı Doğa Koruma ve Milli Parklar Genel Müdürlüğü, Siirt Şube Müdürlüğü, Siirt.

Anonim, (2018). Siirt İli Çevre Durum Raporu. T.C. Çevre ve Şehircilik Bakanlığı Çevre ve Şehircilik İl Müdürlüğü, ÇED ve Çevre İzinleri Şube Müdürlüğü, Siirt.

Anonim, (2019a). Türkiye kültür portalı. T.C. Kültür ve Turizm Bakanlı̆̆ı. https://www.kulturportali.gov.tr/turkiye/siirt/ (Erişim tarihi: 05.08.2019)

Anonim, (2019b). Pistacia vera L. ve Pistacia khinjuk Google görüntüleri.

Çeltek, E. (2004). "Kırsal Turizm ve Tokat İlinin Kırsal Turizm Potansiyelinin S.W.O.T. Analizi”, Yayınlanmamış Yüksek Lisans Tezi, Sakarya Üniversitesi Sosyal Bilimler Enstitüsü, Sakarya.

Dönmez, Y., Türkmen, F., Aytemiz, L., Çabuk, S. (2016). Kırşehir İli Mucur İlçesinin Turizm Potansiyel olanaklarının İncelenmesi. II. Ulusal Sürdürülebilir Turizm Kongresi, 28 - 30 Nisan 2016, Antalya, Türkiye, 406 - 416 s.

GAP Bölge Kalkınma İdaresi Başkanlığı (2019) Siirt İli Profili. T.C. Kalkınma Bakanlığı.

Gülbay, F. (2016). Alternatif Turizme Genel Bir Bakış. I. Ulusal Alternatif Turizm Kongresi, 07-09 Nisan 2016, Erzincan, $217-222$ s.

Mansuroğlu S., Dağ V. (2016). Bingöl İlinin peyzaj potansiyelinin kırsal turizm olanakları (SWOT analizi yöntemi kullanılarak) açısından değerlendirilmesi. Mediterranean Agricultural Sciences, Sayı: 29(1), 9-16 s., Antalya

Olalı, H., Nazilli, S. S., Kırcıoğlu, E. N., Sümer, M. (1983). Dış Tanıtım ve Turizm Türkiye İş Bankası Kültür Yayınları. Ankara.

Ongun, U., ve Gövdere, B. (2014). "Bölgesel Kalkınmada Kırsal Turizmin Etkisi: Ağlasun Yeşilbaşköy Örneği”, International Journal of Social and Sciences, 4 (2), 51-57.

Ongun U., Gövdere B., Çiçek U. (2016). Yeşilova'nın Kırsal Turizm Potansiyelinin SWOT Analizi ile Değerlendirilmesi. SDÜ Vizyoner Dergisi, Cilt: 7, Sayı: 16, 75-88 s., Isparta.

Soykan, F. (1999). Doğal çevre ve kırsal kültürle bütünlesen bir turizm türü: Kırsal turizm. Anatolia Turizm Arastırmaları Dergisi (Türkçe). Y11 :10, Mart-Haziran, 67-75.

Soykan, F. (2003). Kırsal Turizm ve Türkiye Turizmi İçin Önemi. Ege Coğrafya Dergisi, Sayı: 12, İzmir, 1-11 s.

Spatariu, E. C., Trandafir, R. A., and Lazar, C. M. (2010). "The Swot Analysis of the Rural Tourism in the South-Eastern Romania", Ovidius University Annals, 10, 1315-1319.

TÜBIVES, (2015). Siirt İli Taksonları. http://www.tubives.com/ (Erişim tarihi: 20.03.2019)

TÜIK (Türkiye İstatistik Kurumu) (2018) Siirt ili nüfus verileri. https://biruni.tuik.gov.tr/medas/?kn=95\&locale=tr (Erişim tarihi: 05.08.2019)

Topay, M. (2003). Bartın-Uluyayla Peyzaj Özelliklerinin Rekreasyon-Turizm Açısından Değerlendirilmesi Üzerine Bir Araştırma. Doktora tezi. Ankara Üniversitesi Fen Bilimleri Enstitüsü Peyzaj Mimarlığı Anabilim Dalı, 226 s., Ankara.

Yaşaroğlu, Ş. A. (1992). Turizm Bilincini Geliştirme, Turizm Eğitimi Konferansı Workshop, Turizm Bakanlığı Turizm Eğitimi Genel Müdürlüğü. Ankara.

Yıldız, Z., ve Kalağan, G. (2008), 'Alternatif Turizm Kavramı ve Çevresel Etkileri“", Yerel Siyaset Aylık Bilimsel Siyasi Dergi, 35, 42 $-44$ 